\title{
New Developments in the Mechanism of Drug Action and Toxicity of Conjugated Imines and Iminiums, including Related Alkaloids
}

\author{
Peter Kovacic ${ }^{1}$, Ratnasamy Somanathan ${ }^{1,2}$ \\ ${ }^{1}$ Department of Chemistry and Biochemistry, San Diego State University, San Diego, CA, USA \\ ${ }^{2}$ Centro de Graduados e Investigación del Instituto Tecnológico de Tijuana, Tijuana, Mexico \\ Email: rsomanathan@mail.sdsu.edu
}

Received 29 May 2014; revised 30 June 2014; accepted 21 July 2014

Copyright (C) 2014 by authors and Scientific Research Publishing Inc.

This work is licensed under the Creative Commons Attribution International License (CC BY). http://creativecommons.org/licenses/by/4.0/

cC) (i) Open Access

\section{Abstract}

This review deals with mechanism and physiological activity of conjugated imine and iminium species, including those in the alkaloid category. An appreciable number can be found in the Merck Index. There is focus in mode of action on electron transfer (ET), reactive oxygen species (ROS), oxidative stress (OS) and reduction potential in the prior review. These aspects can be involved in both therapeutic action and toxicity. A unifying mechanistic approach involving ET-ROS-OS is applied to synthetic drugs and alkaloids in the imine-iminium category in relation to both beneficial and adverse effects. Insight at the basic, molecular level can aid in practical pharmaceutical design.

\section{Keywords}

Mechanism of Drug, Alkaloids

\section{Introduction}

Electron transfer (ET) functionalities that received the most attention in earlier years are quinone (and phe${ }^{*}$ Corresponding author.

How to cite this paper: Kovacic, P. and Somanathan, R. (2014) New Developments in the Mechanism of Drug Action and Toxicity of Conjugated Imines and Iminiums, including Related Alkaloids. Open Journal of Preventive Medicine, 4, 583-597. http://dx.doi.org/10.4236/ojpm.2014.47068 
nolic precursors) and aromatic nitro compounds (and hydroxylamine and nitroso metabolites). In more recent years, primary-aromatic amins (and hydroxylamine and nitroso metabolites) have been added [1]. Other types receiving increased attention are conjugated imine and iminium species. This category is the focus of the present review in relation to drug types and alkaloids, which represent an extension of the prior report [2]. Scheme 1 depicts redox cycling by the ET functional group with formation of reactive oxygen species (ROS). The initial superoxide is a precursor of hydrogen peroxide and the hydroxyl radical, as illustrated in Scheme 2.

Iminiums are usually better electron acceptors than imines, due partly to positive charge (Scheme 3). In vivo redox cycling with oxygen can occur, giving rise to oxidative stress (OS) through generation of ROS, such as hydrogen peroxide, hydroperoxides, alkyl peroxides, and diverse radicals (hydroxyl, alkoxyl, hydroperoxyl, and superoxide). In some cases, ET results in involvement with normal electrical effects (e.g., in respiration or neu- rochemistry). Generally, active entities possessing ET groups display reduction potentials in the physiological responsive range, (i.e., more positive than about $-0.5 \mathrm{~V}$ ). Hence, ET in vivo can occur resulting in production of ROS which can be beneficial in cell signaling at low concentrations, but produce toxic results at high levels. Electron donors consist of phenols, N-heterocycles or disulfides in proteins which produce relatively stable radical cations. ET, ROS, and OS have been increasingly implicated in the mode of action of drugs and toxins, (e.g., antiinfective agents [3], anticancer drugs [4], carcinogens [5], reproductive toxins [6], nephrotoxins [7], hepato- toxins [8], cardiovascular toxins [9], nerve toxins [10], mitochondrial toxins [11], abused drugs [12], pulmonary toxins [13], ototoxins [14], and various other categories [15].

There is a plethora of experimental evidence supporting the ET-ROS theoretical framework. This evidence includes generation of the common ROS, lipid peroxidation, degeneration products of oxidation, depletion of AOs, effect of exogenous AOs, and DNA oxidation and cleavage products, as well as electrochemical data. This comprehensive, unifying mechanism is consistent with the frequent observations that many ET substances display a variety of activities, e.g., multiple-drug properties, as well as toxic effects. Possible additional modes of action are not discussed since the focus is on ET-ROS-OS.

It is important to recognize that mode of action in the biodomain is often multifaceted. In addition to the ET-ROS-OS approach, other aspects may pertain, such as, enzyme inhibition, allosteric effects, receptor binding, metabolism and physical factors.

The conjugated imines and iminiums in the first section were selected from the Merck Index [16]. It is instructive that an appreciable number of agents in this category can be found as bioactive agents. An important aspect to recognize is that, in many cases, these ET species are generated metabolically. Imines are formed from oxidation of primary and secondary amines, as well as by condensation of carbonyls with primary amines. Iminiums arise from oxidation of tertiary amines and protonation or alkylation of iminies. This category encompasses various imine-iminium types, including iminoquinones and analogs, pyridinium ions, quinolinium ions and higher polynuclear analogs, imines with aromatic conjugation, and others. The aromatic N-heterocycles are iminium-like. There are similar types of conjugated imine-iminiums in the alkaloid class. In both cases, physiological effects are documented.
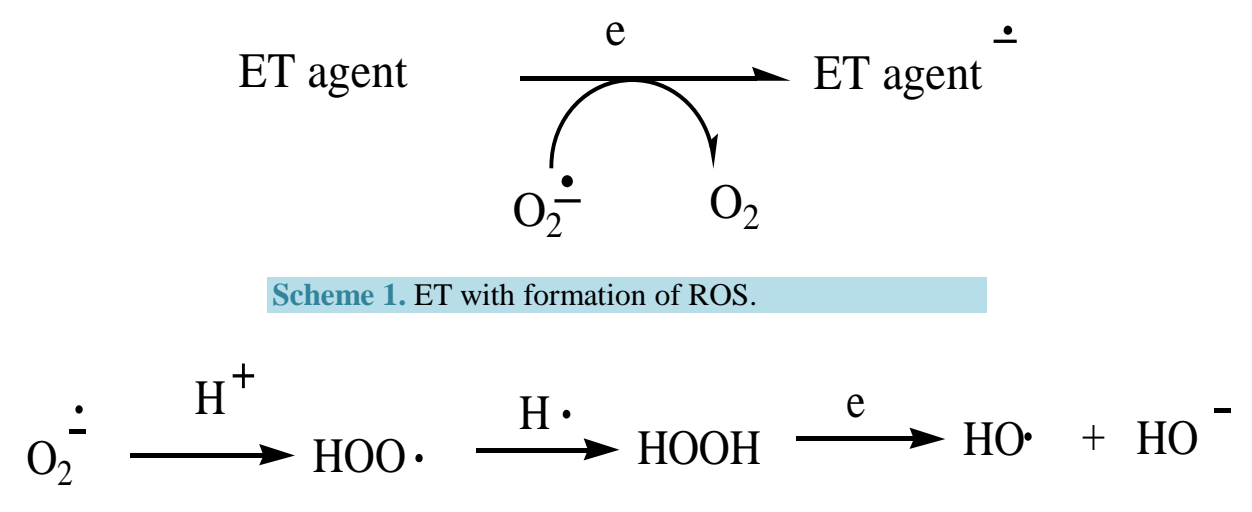

Scheme 2. ROS formation from superoxide. 


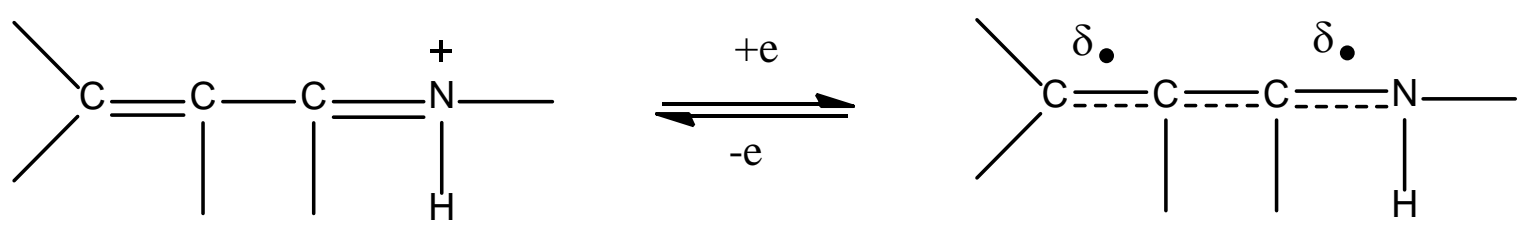

Scheme 3. ET by conjugated iminium.

A purpose of this review is to provide a different perspective in analyzing the biological activity of alkaloids that possess certain structural features which may enhance their ability to act as ET agents. Natural products, with their unique structural features and pronounced biological activities, continue to provide lead structures in the search for new drugs from nature. Invertebrates, such as, sponges, tunicates, and mollusks, have so far provided the largest number of marine -derived secondary products, including some of the most interesting drug candidates. These substances provide a broad and structurally diverse array of pharmacologically active compounds that have proved to be indispensible for the cure of many diseases or as lead structures for novel pharmaceuticals.

There is paucity of information for these compounds in relation to ET-ROS-OS, plus data on reduction potentials and electron affinity. Our aim is for this review to stimulate future research on these missing aspects.

\section{Bioactivity of Conjugated Imines and Iminiums}

These compounds, mostly drugs, are taken from the Merck Index [16] with listing in alphabetical order along with physiological activity. In some cases, the imine moiety could be converted to the electrophilic iminium by intramolecular protonation by carboxyl substituents. Some of the compounds incorporate other potential ET groups. Figures are often abbreviated in order to focus on the conjugated imine or iminium portion. There is a common mechanistic theme applicable to the compounds which can be found in the Introduction.

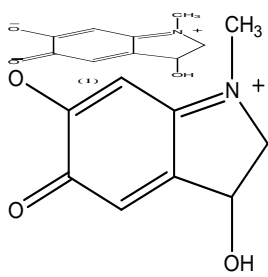

(1)<smiles>[Z6]c1nccc2c1[nH]c1ccccc12</smiles>

(2)<smiles>N=C(N)NC(=O)c1nc(Cl)c(N)nc1N</smiles>

(3)

Adrenochrome (1), psychotomimetic agent; Alstonine (2), antipsychotic [17]; Amiloride (3), diuretic.<smiles>Nc1cnc2nc(N)nc(N)c2n1</smiles>

(4)<smiles></smiles>

(5)

Aminopterin (4), rodenticide; Chlelerythrine (5), anthelmintic [18]. 


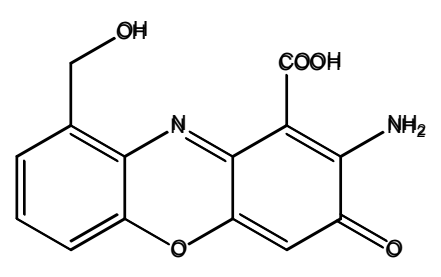

(6)

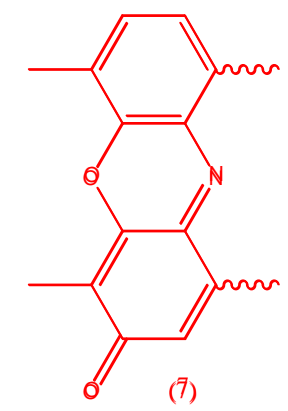

(7)

Cinnabarine (6), antiviral, toxicity and antitumor [19]; Dactinomycin (7), antineoplastic.<smiles>CCC(C)c1cnc(CC(C)C)c(O)[n+]1[O-]</smiles>

(更)<smiles>Cc1nc(-c2ccnc(-c3nnn[nH]3)c2)nc(C)c1C</smiles>

(9)

Aspergillic acid (8), proposed as hypotensive, toxin; Clazosentan (9), treatment of cerebral vasospasm.

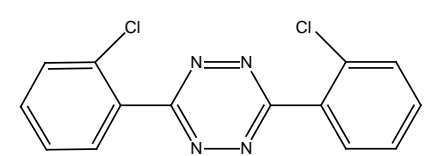

(10)<smiles>c1cc2cc3c(cc2c2c1OCO2)CC[n+]1cc2c(cc1-3)OCO2</smiles>

Clofentezine (10), toxic, bioactive; Coptisine (11), antifungal [20], and antidepressant (monoamine oxidase A inhibitor) [21].<smiles>Cc1cnc2nc(N)nc(O)c2n1</smiles>

(12)<smiles></smiles>

(13)<smiles>Nc1nnc(N)c2ccccc12</smiles>

(14)

Denopterin (12), antineoplastic; Difenzoquat (13), herbicide, fungicide; Dihydralazine (14), antihypertensive.<smiles>CC(C)n1cncn1</smiles>

(15)<smiles>[N-]=[N+]=C1C=NC(=O)NC1=O</smiles>

(16)<smiles>CN=C(C)c1ncccc1C(=O)O</smiles>

(17) 
Diniconazole (15), fungicide; 5-Diazouracil (16), antibacterial, mutagen, DNA cleavage [22]; Diflufenzopyr (17), herbicide.<smiles>Cc1ncc2nc(N)nc(N)c2n1</smiles>

(18)<smiles>Cc1cc(=N)[nH]nc1C</smiles>

(19)<smiles>CCN(C)C1C=CC(=C(N)[18OH])C=C1</smiles>

(20)

Edatrexate (18), antineoplastic; Endralazine (19), antihypertensive; Fast Green FCF (20), clastogenic [23].

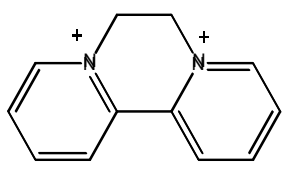

(21)<smiles>Cn1nc2ccccc2n1</smiles>

(를<smiles>CCC(=O)c1cnc2ccccc2n1</smiles>

Diquat (21), herbicide; Drometrizole (22), UV screen; Echinomycin (23), antibacterial [24].<smiles>Cc1cc(=N)[nH]nc1C</smiles>

(24)<smiles></smiles>

(25)<smiles>Cc1nn(C)c(C)c1C=N[O+]</smiles>

(26)

Endralazine (24), antihypertensive; Fazadinium Bromide (25), pharmacology and toxicity; Fenpyroxrimate (26), acaricide.<smiles>N#Cc1nn(N)c(N)c1S(=O)C(F)(F)F</smiles>

(27)<smiles>CCc1ccc2c3[nH]c4ccccc4c3cc[n+]2c1</smiles>

(28)

Fipronil (27), parasiticide; Flavopereirine (28), anticancer [25].<smiles>CN(C)C([Al])C1=NOCCO1</smiles>

(29)<smiles>CC(=NC(=O)c1cccnc1)c1ccco1</smiles>

(30) 
Fluoxastrobin (29), fungicide; Furonazide (30), antibacterial.<smiles>COCc1ccc(C(C)=NCCCO)c(C(=O)O)c1</smiles>

(31)<smiles>Cc1cccc2nonc12</smiles>

(3르)<smiles>CC1=Nc2ccccc2Oc2ccc(Cl)cc21</smiles>

(33)

Imazamox (31), herbicide; Isradipine (32), antihypertensive; Loxzpine (33), anxiolytic.<smiles>N#CC1C=CC(=N[NH-])C=C1</smiles>

(34)<smiles>CN=CC=CNC</smiles>

(35)<smiles>Nc1noc(CC(=O)O)c1N</smiles>

(36)<smiles>CN1CCCN=C1C=CN</smiles>

(37)

Methyl Blue (34), antiseptic; Mitoguazone (35), antineoplastic; Mofezolac (36), analgesic; Oxantel (37), anthelmintic.<smiles>Cc1ccc2nc3sc(=O)sc3nc2c1</smiles>

(38)<smiles>Cc1cc(C)on1</smiles>

(39)

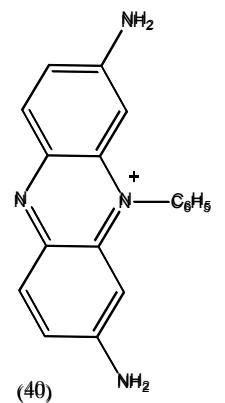

Oxythioquinox (38), fungicide; Perisoxal (39), analgesic; Phenosafranine (40), electron transfer agent [26].<smiles>COc1ccc2nc3cc(Cl)ccc3c(C)c2n1</smiles>

(41)<smiles>O=C(O)CCCCO/N=C(/c1cccnc1)c1cccc(Cl)c1</smiles>

$(42)$

Pyronaridine (41), antimalarial; Ridogrel (42), antithrombotic.<smiles>C[n+]1cc2c3c(ccc2c2ccc4cc5c(cc4c21)OCO5)OCO3</smiles>

(43)<smiles>Cc1cnc2ccccc2n1</smiles>

(44)

Sanguinarine (43), antimicrobial; Sulfaquinoxaline (44), coccidiostat. 
<smiles>Cc1nc(-c2ccnc(-c3nnn[nH]3)c2)nc(C)c1C</smiles><smiles>Cc1nsnc1C</smiles>

(46)

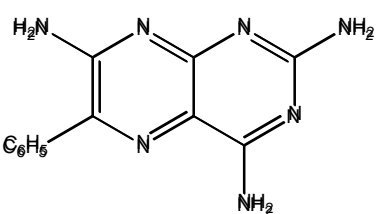

(47)

Tezosentan (45), heart disease; Timolol (46), antihypertensive, antiarrhythmic; Triamterene (47), diuretic.<smiles>Cc1cccc(-c2ccnc3c(C#N)cnn23)c1</smiles>

(48)

Zalepion (48), sedative, hypnotic.

\section{Imine and Iminium Alkaloids}

Most of the ET agents described above are laboratory synthesized molecules and in addition to these a number of naturally occurring alkaloids also fall into the imine and iminium category. Most are isolated from fungi, micro and marine organisms with varied bioactivity.<smiles>[R]Oc1cc2cc3[n+](cc2c(O[R])c1[R])CCc1cc(OC)c([R2])cc1-3</smiles>

Iminium alkaloids (49) with berberine skeletal framework were isolated from Annona glabra. All of them showed acetylchoilnesterase inhibitory properties [27]. A review from 2000 to 2010 [28] deals with anti-in- 
flammatory activity of berberine and other alkaoids.

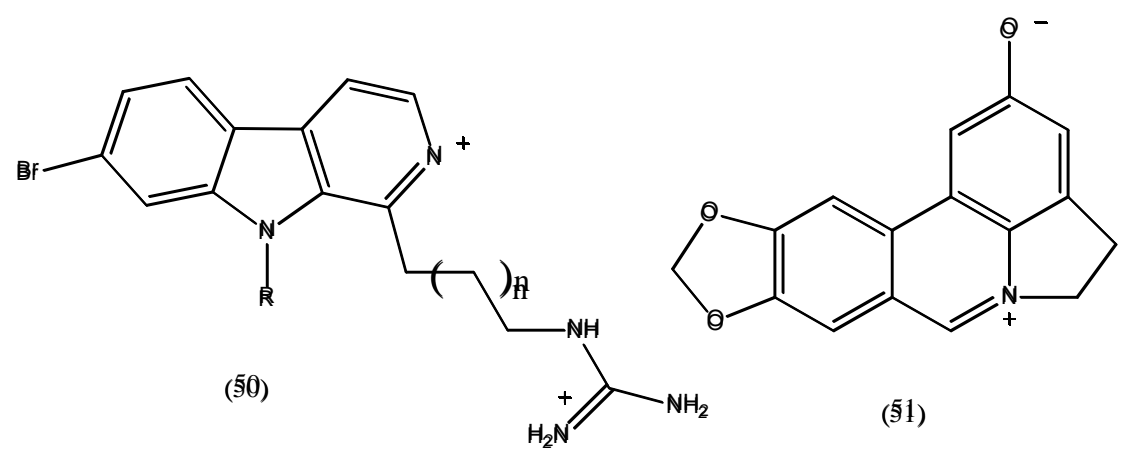

Carboline alkaloids (50) [29] containing an iminium functionality isolated from New Zealand ascidian Pseudodistoma opacum showed antimalarial activity toward a chloroquine-resistant strain of Plasmodium falciparum. Ungermine (51) an Amaryllidaceae alkaloid showed activity against apoptosis-resistant cancer cells [30].<smiles>CN1C(=N)N=C(/N=c2/[nH]c(Cc3ccc4c(c3)OCO4)cn2C)C1=O</smiles>

(51)

Clathridimine (51), isolated from calcareous sponge Clathrina clathrus exhibits broad antimicrobial activity [31].<smiles></smiles>

Synthetic pyrroloquinolines (52) showed a wide range of biological activity, such as DNA intercalation and antileukemic properties [32]. Pyrroloquinolines (53) isolated from gliding bacterium Ohtaekwangia kribbensis showed antibacterial, antifungal and moderate cytotoxicity against growing mammalian cell lines [33]. Ammosamide alkaloids (54), isolated from the marine Strepmyces strain CNR-698, were found to inhibit quinone reductase 2 [34].

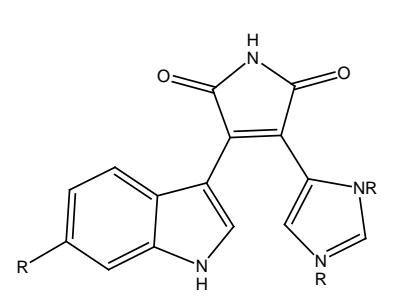

(55)<smiles>O=C1N/C(=N\O)C(c2ccc(F)c(Br)c2)=C1c1ccc(F)c(I)c1</smiles>

(56)

Pyrrolocarbazoles (55) and synthetic analogues were found to inhibit topoisomerase I and diverse kinases [35]. 
Nitrosubstituted maleilides, such as aqabamycin (56) isolated from coral-associated Vibrio sp., showed varying antibacterial activity [36].

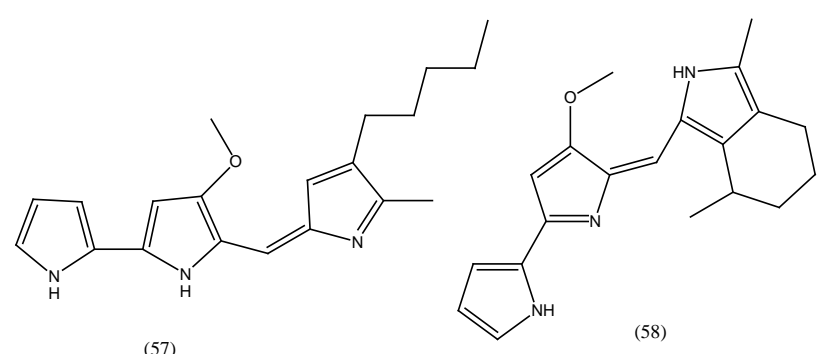<smiles>O=C1NC(c2c[nH]c3ccc(O)cc23)=C/C1=C1/C(=O)Nc2ccccc21</smiles>

The red pigment and antibiotic prodigison (57) and its cyclized analogue (58) isolated from marine Vibrinaceae have a broad range of biological activities, including antimicrobial, antimalarial, immunosuppressive, and anticancer. Prodiginines have clinical potential in anticancer therapy and prodigison (57) is currently in preclinical trials (Aida Pharmaceutical) for pancreatic cancer [36]. Violacein (59), a violet pigment isolated from bacteria of the genus Chromobacterium, has a variety of biological activities, including antiviral, antibacterial, antiulcerogenic, antileishmanial, and anticancer [37].

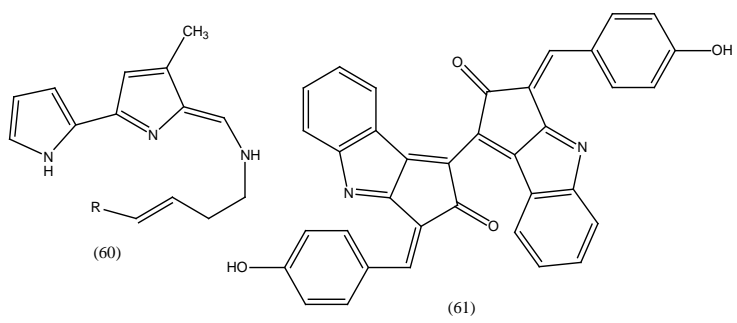

Tambjamines (60) are alkaloids isolated from various marine organisms, such as bryozoans, nudibranches and ascidians, displayed cytotoxic activity against several tumor cells and have a range of antifouling activities [37]. Scytonemin (61), a yellow pigment isolated from aquatic cyanobacteria, forms when the bacteria are exposed to sunlight. The pigment has anti-inflammatory and antiproliferative activities by inhibiting protein kinase $\mathrm{C} \beta$ $(\mathrm{PKC} \beta)$, a well known mediator of the inflammatory process. In addition, the molecule inhibits phorbol-induced mouse ear edema and the proliferation of human umbilical vein endothelial cells [37].<smiles>CC(=O)c1cccc2nc3c(C(C)O)cccc3nc12</smiles>

(鲜)<smiles></smiles>

(63)

RE alkene

More than 6000 phenazine derivatives $(62,63)$ have been identified and described during the last two centuries. Many show antibiotic activities against bacteria, fungi or plant/animal tissues [37]. Phenazines (63) inhibit TNF- $\alpha$-induced NF kB activity and LPS-induced nitric oxide production in mammalian cell culture studies [38]. 
A review deals with bioactive pigments from marine bacteria and their applications and physiological roles [37].<smiles>O=c1nc2c3ccc(Br)cc3nc-2c1=O</smiles>

(64)

Tyrindoleninone (64), isolated from Dicathais orbita, selectively induce apoptosis in female reproductive cancer cells [39].<smiles>Cc1nccc2c1C(C)(C)Nc1cc(I)ccc1-2</smiles>

(65)<smiles>Nc1ncc(-c2ccccc2)c2cnccc12</smiles>

(66)

Veranamine (65), with structural similarities to indoles and cannabinoids was isolated from Verongida rigida, and showed promising antidepressant activity in the forced swim test [40]. Lophocladines B (66), isolated from red alga, possessed moderate cytotoxic activity breast cancer cell lines [41].<smiles>CC(C)=CCn1c2cc(=O)c3cc(C)ccc3c-2nc2c(P)cccc21</smiles>

(67)<smiles>CC(C)=CCn1c2cc(=O)ccc-2nc2c(C(N)=O)cccc21</smiles>

(舫)

Various reports deal with bioactivity of iminoquinones. About 100 phenazine derivatives have been isolated from microorganisms belonging to a wide range of genera. Phenazines $(67,68)$ display a broad range of activities and act as antioxidant, neuroprotectant, broad spectrum antimicrobial, antiparasitic, antiviral, antitumor, and antimalarial agents, affecting a wide range of target organisms [42].<smiles>C[n+]1ccc2c(c1)C(=O)C1=NC=Cc3c-2c2c(O)cccc2c2ccnc1c32</smiles>

(6柦)<smiles>Cn1cc2c(=O)c3nc4ccccc4c4ccnc1c4-c-3=c-c-2=O</smiles>

(71)<smiles>Cc1ccc2nc3c4ccn(C)cc-4c(=O)c4c3c(c2c1)C(=O)C[N+]4(C)C</smiles>

(70)<smiles>Cn1ccc2c(c1=O)C(=O)c1nccc3c1c-2nc1ccccc13</smiles>

(구) 
New pyridoacridine alkaloids $(69,70)$ were isolated from the sponge Xestosponia carbonaria along with the known amphimedine (71) and neoamphimedine (72). Amphimedine (71) was the only compound that caused a phenotype in zebrafish embryos [43]. Another study showed that amphimedine (72) acts as anticancer agent by inhibiting. TopoII $\alpha$-dependent DNA decantation in the presence of metnase [44].<smiles>COc1cc2ccnc3c2c(c1N)C(=O)c1ccccc1-3</smiles>

(73)<smiles>COc1cc2c3c(nccc3c1[N+](=O)[O-])-c1ccccc1C2=O</smiles>

(74)

Lakshminine (73), belonging to a family of oxoisoaporphine alkaloids, including (74) showed marginal antiproliferative activity against human normal fibroblasts and human solid tumor cell lines [45].<smiles>O=C(NCCCNC1=CC(=O)c2nc3ccccc3c3ccnc1c23)c1cnccn1</smiles>

Ascididemin (75), a marine-derived pyridoacridine alkaloid, is known to exert cytotoxicity via inhibition of DNA topoisomerase II, leading to cleavage of DNA and cell death. These cytotoxic effects clearly limit the potential antibiotic utility of the natural product. Two synthetic analogues (76) were found to inhibit growth of Mycobacterium tuberculosis, with negligible cytotoxicity [46].<smiles>CCCc1c2c(c3nccc4c3c1-c1ccccc1N4)SCC(=O)CC(=O)N2</smiles>

Several new pyridoacridine alkaloids $(77,78)$ isolated from different Ascidian species showed antimicrobial properties [47]. A review deals with alkaloids from marine Ascidians, highlighting their potential as therapeutic agents for the treatment of cancer or viral infections [48].<smiles></smiles> 
Synthetic pyrroloiminoquinone (79) BA-TPQ, based on natural alkaloid makaluvamine scaffold, showed promise as an anti-breast cancer agent [49] [50].<smiles>CC1=C2NCC3c4ccccc4N=C2C3C2=C1C(=O)CCN2</smiles>

(䀦)<smiles></smiles>

(81)

Marine invertebrate-derived polycyclic heteroaromatic alkaloids with 16-18 $\pi$ electron containing cores are relevant for therapeutic development, as they interfere with many biological disease targets [51]. Pyrroloacridine alkaloid (80), isolated from Plakortis quasiamphiaster, exhibited cytotoxicity against human colon H-116 cells, but showed no effects against yeast diploid homozygous delection strain of topoisomerase. By contrast, alkaloid (81) was inactive against H-116 cells, but was potent in the yeast halo screen [51].<smiles>CNc1cc2nc3cc(CO)ccc3oc-2cc1=O</smiles>

(盽)

Two phenoxazinone alkaloids, chandrananimycin and pitucamycin (82), isolated from Streptomyces grieus, exhibited antimicrobial, antproliferative and cytotoxic activities against a number of tumor cell lines [52].

\section{Acknowledgements}

Editorial assistance by Thelma Chavez is acknowledged.

\section{References}

[1] Kovacic, P. and Somanathan, R. (2011) Novel, Unifying Mechanism for Aromatic Primary-Amines (Therapeutic, Carcinogens and Toxins). Medicinal Chemistry Communication, 2, 106-112.

[2] Kovacic, P. and Somanathan, R. (2010) Mechanism of Conjugated Imine and Iminium Species, including Marine Alkaloids; Electron Transfer, Reactive Oxygen Species, Therapeutics and Toxicity. Current Bioactive Compounds, 6, 4659. http://dx.doi.org/10.2174/157340710790711782

[3] Kovacic, P. and Becvar, L.E. (2000) Mode of Action of Anti-Infective Agents: Emphasis on Oxidative Stress and Electron Transfer. Current Pharmaceutical Design, 6, 143-167. http://dx.doi.org/10.2174/1381612810006020143

[4] Kovacic, P. and Osuna, JA. (2000) Mechanisms of Anticancer Agents: Focus on Oxidative Stress and Electron Transfer. Current Pharmaceutical Design, 6, 277-309. http://dx.doi.org/10.2174/1381612003401046

[5] Kovacic, P. and Jacintho, J.D. (2001) Mechanisms of Carcinogensis: Focus on Oxidative Stress and Electron Transfer. Current Medicinal Chemistry, 8, 773-796. http://dx.doi.org/10.2174/0929867013373084

[6] Kovacic, P. and Jacintho, J.D. (2001) Reproductive Toxins: Pervasive Theme of Oxidative Stress and Electron Transfer. Current Medicinal Chemistry, 8, 863-892. http://dx.doi.org/10.2174/0929867013372878

[7] Kovacic, P., Sacman, A. and Wu-Weis, M.N. (2002) Widespread Role of Oxidative Stress and Electron Transfer. Current Medicinal Chemistry, 9, 823-847. http://dx.doi.org/10.2174/0929867024606803

[8] Poli, G., Cheeseman, K.H., Dianzani, M.U. and Slater, T.F. (1989) Free Radicals in the Pathogenesis of Liver Injury. Pergamon, New York, 1-330.

[9] Kovacic, P. and Thurn, L.A. (2005) Cardiovascular Toxins from the Perspective of Oxidative Stress and Electron Transfer. Current Vascular Pharmacology, 3, 107-117. http://dx.doi.org/10.2174/1570161053586912

[10] Kovacic, P. and Somanathan, R. (2005) Neurotoxicity: The Broad Framework of Electron Transfer, Oxidative Stress and Protection by Antioxidants. Current Medicinal Chemistry, 5, 2601-2623. 
http://dx.doi.org/10.2174/092986705774370646

[11] Kovacic, P., Pozos, R.S., Somanathan, R., Shangari, R. and O’Brien, P.J. (2005) Mechanism of Mitochondrial Uncouplers, Inhibitors, and Toxins: Focus on Electron Transfer, Free Radicals, and Structure-Activity Relationships. Current Medicinal Chemistry, 5, 2601-2623. http://dx.doi.org/10.2174/092986705774370646

[12] Kovacic, P. and Cooksy, A.L. (2005) Unifying Mechanism for Toxicity and Addiction by Abused Drugs: Electron Transfer and Reactive Oxygen Species. Medical Hypotheses, 64, 366-367. http://dx.doi.org/10.1016/j.mehy.2004.07.021

[13] Kovacic, P. and Somanathan, R. (2009) Pulmonary Toxicity and Environmental Contamination: Radicals, Electron Transfer, and Protection by Antioxidants. Reviews of Environmental Contamination and Toxicology, 201, 41-69.

[14] Kovacic, P. and Somanathan, R. (2008) Ototoxicity and Noise Trauma; Electron Transfer, Reactive Oxygen Species, Cell Signaling, Electrical Effects, and Protection by Antioxidants; Practical Medical Aspects. Medical Hypotheses, 70, 914-923. http://dx.doi.org/10.1016/j.mehy.2007.06.045

[15] Halliwell, B. and Gutteridge, J.M.C. (1999) Free Radicals in Biology and Medicine. Oxford University Press, New York, 1-897.

[16] O’Neil, M.J. (2006) The Merck Index. 14th Edition, Whitehouse Station, Hunterdon County, 1-10197.

[17] Costa-Campos, L., Lara, D.R., Nunes, D.S. and Elisabetsky, E. (1998) Antipsychotic-Like Profile of Alstonine. Pharmacology Biochemistry and Behavior, 60, 133-141. http://dx.doi.org/10.1016/S0091-3057(97)00594-7

[18] Li, X.L., Yao, J.Y., Zhou, Z.M., Shen, J.Y., Ru, H.S. and Liu, X.L. (2011) Activity of the Cheleythrine, a Quaternary Benzo[c]Phenanththridine Alkaloid from Chelidonium majus L. on Dactylogyrus intermedius. Parasitology Research, 109, 247-252. http://dx.doi.org/10.1007/s00436-011-2320-9

[19] Smânia, A., Marques, C.J.S., Smânia, E.F.A., Zanetti, C.R., Carobrez, S.G., Tramonte, R. and Loguercio-Leite, C. (2003) Toxicity and Antiviral Activity of Cinnabarin Obtained from Pycocarpus sanguieus (Fr.) Murr. Phytotherapy Research, 17, 1069. www.interscience.wiley.com

[20] Kong, W.J., Zhao, Y.L., Xiao, X.H., Li, Z.L., Jin, C. and Li, H.B. (2009) Investigation of the Anti-Fungal Activity of Coptisine on Candida albicans Growth by Microcalori, Etry Combines with Principal Component Analysis. Journal of Applied Microbiology, 107, 1072-1080. http://dx.doi.org/10.1111/j.1365-2672.2009.04292.x

[21] Ro, J.S., Lee, S.S., Lee, K.S. and Lee, M.K. (2001) Inhibition of Type a Monamine Oxidase by Coptisine in Mouse Brain. Life Sciences, 70, 639-645. http://dx.doi.org/10.1016/S0024-3205(01)01437-0

[22] Hiramoto, K., Kato, T. and Kikugawa, K. (1994) Mechanism of the DNA Breaking Activity of Mutagenic 5-Diazouracil. Mutation Research, 306, 153-163. http://dx.doi.org/10.1016/0027-5107(94)90026-4

[23] Misra, R.N. and Misra, B. (1986) Genetic Toxicological Testing of Some Dyes by the Micronucleus Test. Mutation Research/Genetic Toxicology, 170, 75-78. http://dx.doi.org/10.1016/0165-1218(86)90083-2

[24] Kim, J.-B., Lee, G.-S., Kim, Y.-B., Kim, S.-K. and Kim, Y.-H. (2004) In Vitro Antibacterial Activity of Echinomycin Abd a Novel Analogue, YK2000, against Vancomicina Resistant Enterococci. International Journal of Antimicrobial Agents, 24, 613-615. http://dx.doi.org/10.1016/j.ijantimicag.2004.03.018

[25] Beljanski, M. and Beljanski, M.S. (1982) Selective Inhibition of in Vitro Synthesis of Cancer DNA by Alkaloids BetaCarboline Class. Experimental Cell Biology, 50, 79-87.

[26] Broglia, M.F., Bertolotti, S.G. and Previtali, C.M. (2007) Proton and Electron Transfer in the Excited State Quenching of Phenosafranine by Aliphatic Amines. Photochemistry and Photobiology, 83, 535-541. http://dx.doi.org/10.1562/2006-07-31-RA-989

[27] Tsai, S.F. and Lee, S.S. (2010) Characterization of Acetylcholinesterase Inhibitory Constituents from Annona glabra Assisted by HPLC Microfractionation. Journal of Natural Products, 73, 1632-1635. http://dx.doi.org/10.1021/np100247r

[28] Souto, A.L., Tavares, J.F., da Silva, M.S., de Fátima Formiga Melo Diniz, M., de Athayde-Filho, P.F. and Filho, J.M.B. (2011) Anti-Inflammatory Activity of Alkaloids: An Update from 2000 to 2010. Molecules, 16, 8515-8534. http://dx.doi.org/10.3390/molecules16108515

[29] Chan, S.T.S., Pearce, A.N., Page, M.J., Kaiser, M. and Copp, B.R. (2011) Antimalarial $\beta$-Carbolines from the New Zealand Ascidian Pseudodistoma opacum. Journal of Natural Products, 74, 1972-1979. http://dx.doi.org/10.1021/np200509g

[30] Goietsenoven, G.V., Andolfi, A., Lallemand, B., Cimmino, A., Lamoral-Theys, D., Gras, T., Abou-Donia, A., Dubois, J., Lefranc, F., Mathieu, V., Kornienko, A., Kiss, R. and Evidente, A. (2010) Amaryllidaceae Alkaloids Belonging to Different Structural Subgroups Display Activity against Apoptosis-Resistant Cancer Cells. Journal of Natural Products, 73, 1223-1227. http://dx.doi.org/10.1021/np9008255 
[31] Roué, M., Domart-Coulon, I., Reskovsky, A., Djediat, C., Perez, T. and Bourguet-Kondracki, M.L. (2010) Cellular Localization of Clathridimine, an Antimicrobial 2-Aminoimidazole Alkaloid Produced by the Mediterranean Calcareous Spomge Clathrina clathrus. Journal of Natural Products, 73, 1277-1282. http://dx.doi.org/10.1021/np100175x

[32] Boisse, T., Gautret, P., Rigo, B., Goossens, L., Hénichart, J.P. and Gavara, L. (2008) A New Synthesis of pyrrolo[3,2,b]quinolines by Tandem Electrocyclization-Oxidation Process. Tetrahedron, 64, 7266-7272. http://dx.doi.org/10.1016/j.tet.2008.05.071

[33] Okanya, P.W., Mohr, K.I., Gerth, K., Jansen, R. and Müller, R. (2011) Marinoquinolines A-F, Pyrroloquinolines from Ohtaewangia Kribbensis (Bacteridetes). Journal of Natural Products, 74, 603-608. http://dx.doi.org/10.1021/np100625a

[34] Reddy, P.V.N., Jensen, K.C., Mesecar, A.D., Fanwick, P.E. and Cushman, M. (2011) Design, Synthesis, and Biological Evaluation of Potent Quinoline and Pyrroloquinoline Ammosamide Analogues as Inhibitors of Quinone Reductase 2. Journal of Medicinal Chemistry, 55, 367-377. http://dx.doi.org/10.1021/jm201251c

[35] Deslanders, S., Chassaing, S. and Delfourne, E. (2009) Marine Pyrrolocarbazoles and Analogues: Synthesis and Kinase Inhibition. Marine Drugs, 7, 754-786. http://dx.doi.org/10.3390/md7040754

[36] Mansson, M., Gram, L. and Larsen, T.O. (2011) Production of Bioactive Secondary Metabolites by Marine Vibrinaceae. Marine Drugs, 9, 1440-1468. http://dx.doi.org/10.3390/md9091440

[37] Soliev, A.B., Hosokawa, K. and Enomoto, K. (2011) Bioactive Pigments from Marine Bacteria: Applications and Physiological Roles. Evidence-Based Complementary and Alternative Medicine, 2011, Article ID: 670349. http://dx.doi.org/10.1155/2011/670349

[38] Kondratyuk, T.P., Park, E.J., van Breeman, R.B., Asolkar, R.N., Murphy, B.T., Fenical, W. and Pezzuto, J.M. (2012) Novel Marine Phenazines as Potential Cancer Chemopreventive and Anti-Inflammatory Agents. Marine Drugs, 10, 451-464. http://dx.doi.org/10.3390/md10020451

[39] Edwards, V., Benkendorff, K. and Young, F. (2012) Marine Compounds Selectively Induce Apoptosis in Female Reproductive Cancer Cells, but Not in Primary-Derived Human Reproductive Granulose Cells. Marine Drugs, 10, 64-83. http://dx.doi.org/10.3390/md10010064

[40] Kochanowska-Karamyan, A.J. and Hamann, M.T. (2010) Marine Indole Alkaloids: Potential New Drug Leads for the Control of Depression and Anxiety. Chemical Reviews, 110, 44989-4497. http://dx.doi.org/10.1021/cr900211p

[41] Güven, K.C., Percot, A. and Sezik, E. (2010) Alkaloids in Marine Algae. Marine Drugs, 8, 269-284. http://dx.doi.org/10.3390/md8020269

[42] Zendah, I., Riaz, N., Nasr, H., Frauendorf, H., Schüffler, A., Raies, A. and Laatsch, H. (2012) Chromophenazines from the Terrestrial Streptomyces sp. Ank 315. Journal of Natural Products, 75, 2-8. http://dx.doi.org/10.1021/np100818d

[43] Wei, X., Bugni, T.S., Harper, M.K., Sandoval, I.T., Manos, E.J., Swift, J., Van Wagoner, R.M., Jones, D.A. and Ireland, C.M. (2010) Evaluation of Pyridoacridine Alkaloids in a Zebrafish Phentypis Assya. Marine Drugs, 8, 1769-1778. http://dx.doi.org/10.3390/md8061769

[44] Ponder, J., Yoo, B.H., Abraham, A.D., Li, Q., Ashley, A.K., Amerin, C.L., Zhou, Q., Reid, B.G., Reigan, P., Hromas, R., Nickoloff, J.A. and LaBarbera, D.V. (2011) Neoamphimedine Circumvents Metnase-Enhanced DNA Topoisomerase Ii $\alpha$ Activity through ATP-Competitive Inhibition. Marine Drugs, 9, 2397-2408. http://dx.doi.org/10.3390/md9112397

[45] Castro-Castillo, V., Rebolledo-Fuentes, M., Theoduloz, C. and Cassels, B.K. (2010) Synthesis of Lakshminine and Antiproliferative Testing of Related Oxoisoaporphines. Journal of Natural Products, 73, 1951-1953. http://dx.doi.org/10.1021/np100370g

[46] Appleton, D.R., Pearce, A.N. and Copp, B.R. (2010) Anti-Tuberculosis Natural Products: Synthesis and Biological Evaluation of Pyridoacridine Alkaloids Related to Ascididemin. Tetrahedron, 66, 4977-4986. http://dx.doi.org/10.1016/j.tet.2010.05.033

[47] Bontemps, N., Bry, D., Lòpez-Legentil, S., Simon-Levert, A., Long, C. and Banaigs, B. (2010) Structures and Antimicrobial Activities of Pyridoacridine Alkaloids Isolated from Different Chromotypes of the Ascidian Cystodytes dellechiajei. Journal of Natural Products, 73, 1044-1048. http://dx.doi.org/10.1021/np900751k

[48] Menna, M., Fattorusso, E. and Imperatore, C. (2011) Alkaloids from Marine Ascidians. Molecules, 16, 8694-8732. http://dx.doi.org/10.3390/molecules16108694

[49] Wang, W., Rayburn, E.R., Sadanandan, E.V., Chen, D., Nadkarni, D.H., Murugesan, S., Chen, D.Q. and Zhang, R.W. (2010) A Novel Synthetic Iminoquinone, BA-TPQ, as an Anti-Breast Cancer Agent: In Vitro and in Vivo Activity and Mechanism of Action. Breast Cancer Research and Treatment, 123, 321-331. http://dx.doi.org/10.1007/s10549-009-0638-0

[50] Ezell, S.J., Li, H., Xu, H., Zhang, X., Gurpinar, E., Zhang, X., Rayburn, E.R., Sommers, C.I., Yang, X., Velu, S.E., 
Wang, W. and Wang, R.W. (2010) Preclinical Pharmacology of BA-TPQ, a Novel Synthetic Iminoquinone Anticancer Agent. Marine Drugs, 8, 2129-2141. http://dx.doi.org/10.3390/md8072129

[51] Ralifo, P., Sanchez, L., Gassner, N.C., Tenney, K., Lokey, R.S., Holman, T.R., Valeriote, F.A. and Crews, P. (2007) Pyrroloacridine Alkaloids from Plakortis quasiamphiaste: Structures and Bioactivity. Journal of Natural Products, 70, 95-97. http://dx.doi.org/10.1021/np060585w

[52] Gomes, P.B., Nett, M., Dahse, H.M. and Hertweck, C. (2010) Pitucamycin: Structural Merger of a Phenoxazinone with Epoxyquinone Antibiotic. Journal of Natural Products, 73, 1461-1464. http://dx.doi.org/10.1021/np100344u 